Review

\title{
Prevalence of Chagas disease in Brazil: A systematic review and meta-analysis
}

\author{
Francisco Rogerlândio Martins-Melo ${ }^{\mathrm{a}, *}$, Alberto Novaes Ramos Jr ${ }^{\mathrm{a}}$, \\ Carlos Henrique Alencar ${ }^{\mathrm{a}}$, Jorg Heukelbach ${ }^{\mathrm{a}, \mathrm{b}, * *}$ \\ a Department of Community Health, School of Medicine, Federal University of Ceará, 60430-140 Fortaleza, Brazil \\ ${ }^{\mathrm{b}}$ Anton Breinl Centre for Public Health and Tropical Medicine, School of Public Health, Tropical Medicine and Rehabilitation Sciences, James Cook \\ University, Townsville, QLD 4811, Australia
}

\section{A R T I C L E I N F O}

\section{Article history:}

Received 8 July 2013

Received in revised form 30 August 2013

Accepted 1 October 2013

Available online 15 October 2013

\section{Keywords:}

Chagas disease

Trypanosoma cruzi

Brazil

Prevalence

Epidemiology

Systematic review

\begin{abstract}
A B S T R A C T
Chagas disease is a major public health problem in Brazil and Latin America. During the last years, it has become an emerging problem in North America and Europe due to increasing international migration. Here we describe the prevalence of Chagas disease in Brazil through a systematic review. We searched national and international electronic databases, grey literature and reference lists of selected articles for population-based studies on Chagas disease prevalence in Brazil, performed from 1980 until September 2012. Forty-two articles with relevant prevalence data were identified from a total of 4985 references. Prevalence ranged from $0 \%$ to $25.1 \%$. Most surveys were performed in the Northeast region, especially in the state of Piauí. We observed a high degree of heterogeneity in most pooled estimates $\left(I^{2}>75 \%\right.$; $p<0.001)$. The pooled estimate of Chagas disease prevalence across studies for the entire period was $4.2 \%$ (95\% CI: 3.1-5.7), ranging from 4.4\% (95\% CI: $2.3-8.3$ ) in the 1980 s to $2.4 \%$ (95\% CI: $1.5-3.8)$ after 2000. Females (4.2\%; 95\% CI: 2.6-6.8), >60 year-olds (17.7\%; 95\% CI: $11.4-26.5)$, Northeast (5.0\%; $95 \%$ CI: 3.1-8.1) and Southeast (5.0\%; CI: 2.4-9.9) regions and mixed (urban/rural) areas (6.4\%; 95\% CI: 4.2-9.4) had the highest pooled prevalence. About 4.6 million ( $95 \% \mathrm{CI}: 2.9-7.2$ million) of people are estimated to be infected with Trypanosoma cruzi. The small number of studies and small-scale samples of the general population in some areas limit interpretation, and findings of this review do not necessarily reflect the situation of the entire country. Systematic population-based studies at regional and national level are recommended to provide more accurate estimates and better define the epidemiology and risk areas of Chagas disease in Brazil.
\end{abstract}

(c) 2013 Elsevier B.V. All rights reserved.

\section{Contents}

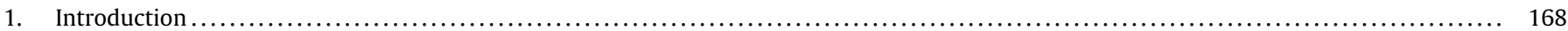

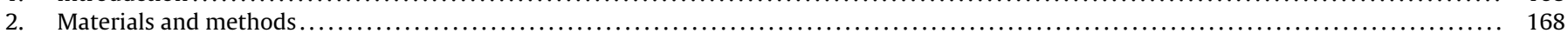

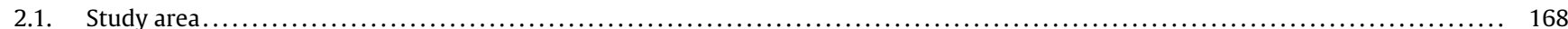

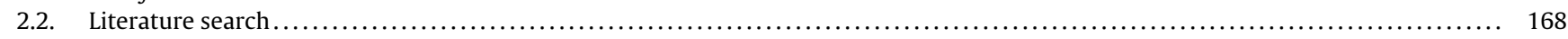

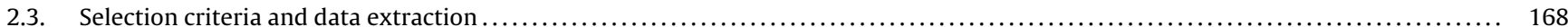

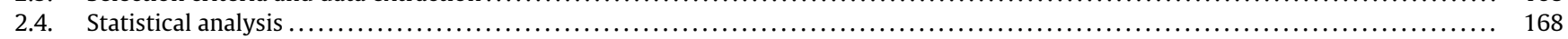

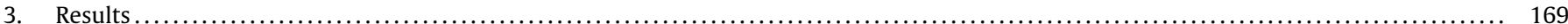

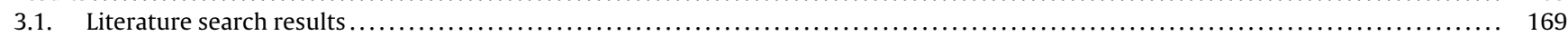

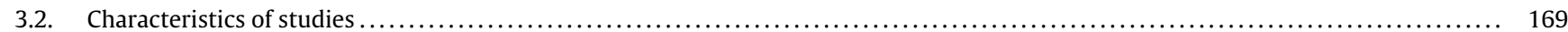

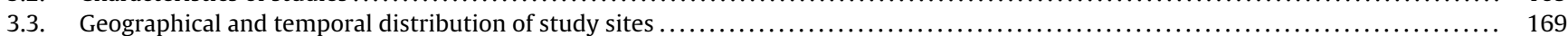

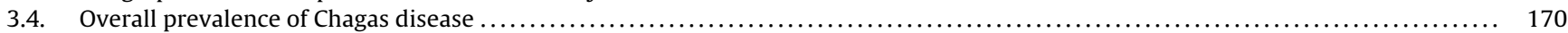

\footnotetext{
* Corresponding author. Tel.: +55 8533668045 .

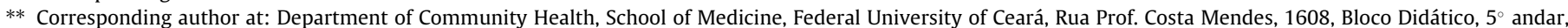
Bairro Rodolfo Teófilo, 60430-140 Fortaleza, Brazil. Tel.: +55 8533668045.

E-mail addresses: rogerlandio@bol.com.br (F.R. Martins-Melo), heukelbach@web.de (J. Heukelbach).
} 


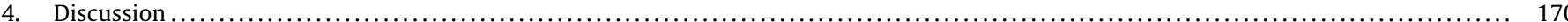

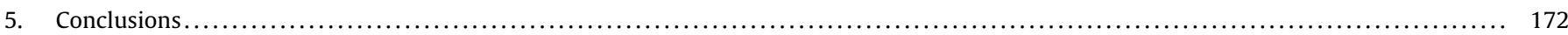

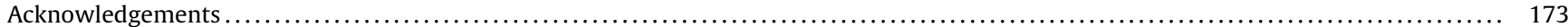

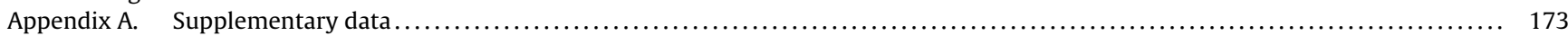

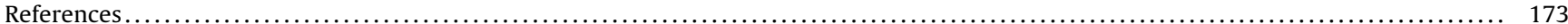

\section{Introduction}

Chagas disease is a Neglected Tropical Disease (NTD) and a major public health problem in Latin America (Moncayo and Silveira, 2009). During the last years, the disease has received increasing attention as an emerging problem in North America and Europe due to international migrations from endemic areas to non-endemic areas (Gascon et al., 2010; Schmunis and Yadon, 2010). There are about of 8-10 million infected people in Latin America (Schmunis and Yadon, 2010; WHO, 2010), with an annual death toll of about 14,000 (WHO, 2010).

After significant reduction of vector and transfusional transmission of Trypanosoma cruzi in Brazil, the number of cases with the acute form of Chagas disease has been reduced dramatically (Silveira, 2011a). Reduced specific mortality and increased survival of infected individuals is a consequence of better knowledge about the natural history of the disease and improved clinical and surgical care (Martins-Melo et al., 2012e; Martins-Melo and Heukelbach, 2013; Ramos Jr. et al., 2010). Recent estimates point to 2-3 million infected people in Brazil (Akhavan, 2000; Dias, 2007; Ramos Jr. et al., 2010), with about 6000 deaths annually (Martins-Melo et al., 2012a,b,d).

However, systematic data about the magnitude of Chagas disease in the general population and its distribution in Brazil's regions are not available (Camargo et al., 1984; Silveira et al., 2011). Such information is needed to optimize health resources allocation towards improvement on disease detection, treatment and control. In the present study we estimate the prevalence of Chagas disease in Brazil through a systematic review and meta-analysis of available population-based studies.

\section{Materials and methods}

\subsection{Study area}

Brazil, South America's largest country, has a total territory of 8.5 million $\mathrm{km}^{2}$ and an estimated population of 194 million (2012). The country is divided into five geographic regions (South, Southeast, Central-West, North, and Northeast), 27 Federative Units (26 States and one Federal District) and 5570 municipalities. Despite the economic improvements that have given the country new international recognition and projection, there are still tremendous social and economic inequalities, evidenced by differing human development indexes (HDI) among regions and rural/urban areas (Instituto Brasileiro de Geografia e Estatística IBGE; http://www.ibge.gov.br).

\subsection{Literature search}

We performed a systematic review of available literature to identify relevant publications about prevalence data of Chagas disease in Brazil. A comprehensive search was conducted in the electronic databases PubMed, Web of Science, Scopus, LILACS and SciELO (covering all dates from the creation of each database up to September 31, 2012), using the following keywords and their combinations: "Chagas disease", "Trypanosoma cruzi", "American trypanosomiasis", "prevalence”, "epidemiology" and "Brazil”. Different combinations were used for each electronic database in order to narrow the amount of results retrieved, but at the same time maximizing the number of relevant studies. At that point, no restrictions were made regarding date of publication, study design, or language of publication. Additional strategies included reviews of journals/periodicals not indexed in the above mentioned electronic databases, internet searches for "grey literature" and screening of reference lists of selected studies. If necessary, the corresponding authors of relevant studies were contacted. Brazilian experts in the field were contacted to detect other potential unpublished studies.

\subsection{Selection criteria and data extraction}

Reference Manager bibliographic software version 11.0 (Thomson Reuters, New York, NY, United States of America) was used to catalogue the initial literature search results and to manage citations. Titles and abstracts were assessed, and respective papers examined in full for prevalence survey data.

We included studies if all of the following inclusion criteria were met: survey date after 1980; conducted in Brazil; population-based study; number of $T$. cruzi-infected individuals and size of study population available; and use of conventional serological tests for confirmation of infection by T. cruzi (e.g., indirect immunofluorescence assay [IFA], enzyme-linked immunosorbent assay [ELISA] and indirect hemagglutination assay [IHA]). We included studies after 1980, as the last major national survey of seroprevalence of $T$. cruzi infection in the general population in Brazil was performed 1975-1980 (Camargo et al., 1984; Silveira et al., 2011).

The following studies were excluded: based on secondary data; duplicated data; no clear definition of methods, especially sampling; non-population based studies such as hospital-based data, clinical studies, case series and case control studies. In the case of repeated surveys in the same population, most recent and/or more complete data were included.

Prevalence data of Chagas disease were extracted from included studies. Prevalence of Chagas disease was defined as the frequency of cases by $T$. cruzi infection in a given population at a given period of time. The information on the study and population characteristics were extracted of all relevant studies, including the author's name, study period, survey geographic location, sample size, age group, number of positive cases, and type of serological test utilized.

\subsection{Statistical analysis}

Data analysis was carried out in different steps. First, mean prevalences were calculated for grouped data in sub-periods (1980-1989, 1990-1999 and after 2000) and region of residence (Brazilian states and regions), using the sum of the numbers of cases in all studies considered, divided by the sum of the number of participants. The $95 \%$ confidence interval (95\% CI) was computed using exact binomial method. If the study did not report the year of data collection, the year of publication was used. Then, pooled prevalence estimates for Chagas disease in the general population and their 95\% CI were calculated using the random-effects model meta-analysis (Hedges and Vevea, 1998). Heterogeneity betweenstudy was evaluated through Cochran's $Q$ test (reported as $\chi^{2}$ and $p$ values) and $I^{2}$ statistic, which describes the percentage of variation between studies (values of $25 \%, 50 \%$, and $75 \%$ show low, 


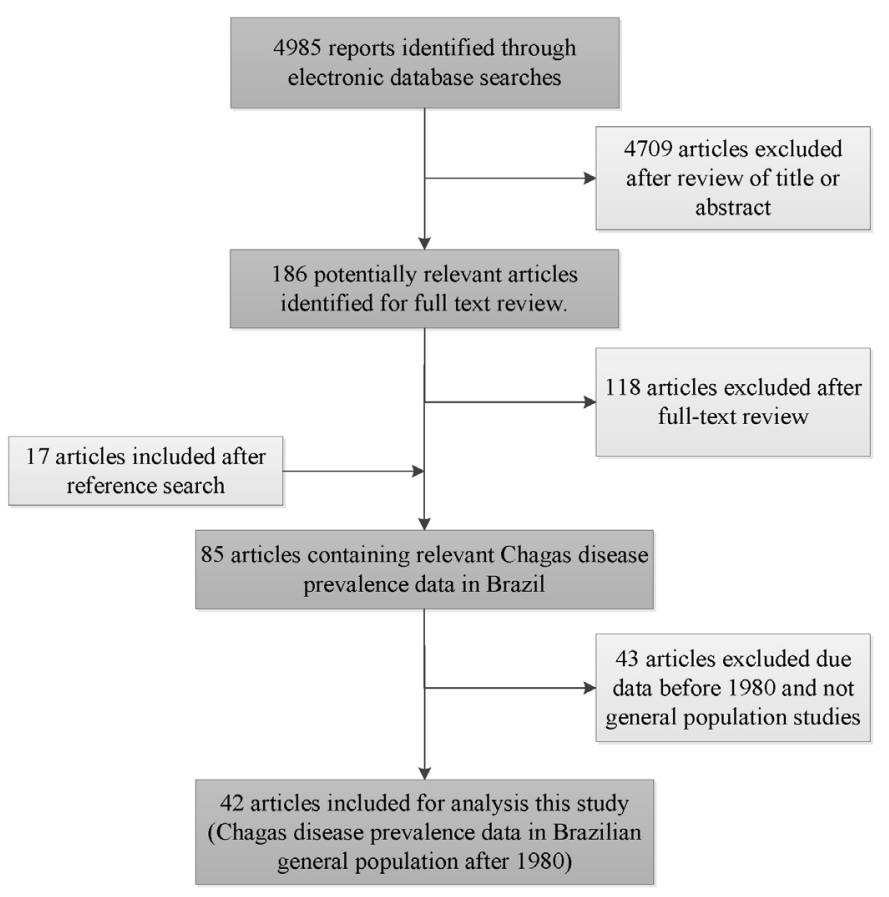

Fig. 1. Flow chart of selection of studies

moderate, and high degrees of heterogeneity, respectively) (Higgins et al., 2003; Huedo-Medina et al., 2006). Subgroup analyses included were performed to investigate potential sources of heterogeneity among studies and included the following variables: geographical region, sex, age group (0-9, 10-19, 20-29, 30-39, $40-49,50-59,>60$ years), sample size, survey period, urban or rural area, and type of serological test. Data are presented including prevalence with corresponding $95 \% \mathrm{CI}$ for each study and the overall random-effects pooled estimate. To estimate the current number of T. cruzi infected individuals at national level, we used the pooled prevalence estimate in 2000s and population data from the Brazilian Institute of Geography and Statistics (IBGE), based on the 2010 National Population Census.

Data were analyzed using Stata software version 11.2 (Stata Corporation, College Station, United States of America) and Comprehensive Meta-Analysis software version 2.0 (Biostat, Englewood, United States of America). A map detailing prevalence at study sites was created, using ArcGIS software version 9.3 (Environmental Systems Research Institute, Redlands, CA, United States of America).

\section{Results}

\subsection{Literature search results}

Of 4895 articles identified, 42 were considered eligible for the review (Aras et al., 2002; Arruda et al., 1984; Bento et al., 1984; Bento et al., 1989; Bento et al., 1992; Bezerra et al., 1983; Boia et al., 1999; Borges-Pereira et al., 2001; Borges-Pereira et al., 2002; Borges-Pereira et al., 2006; Borges-Pereira et al., 2008; Brito et al., 2012; Carvalho et al., 2011a; Carvalho et al., 2003; Carvalho et al., 2011b; Coimbra et al., 1992; Corrêa et al., 2011; Coura et al., 1995a; Coura et al., 1995b; Coura et al., 2002; Dantas-Maia et al., 2007; Dias et al., 2002a; Diotaiuti et al., 2000; Escolano et al., 1989; Figueredo-Silva et al., 1991; Fonsêca et al., 2012; Gazin et al., 2004; Lima et al., 2012; Luitgards-Moura et al., 2005; Machado et al., 1998; Magalhães et al., 2011; Massaro et al., 2008; Montoya et al., 2003; Passos et al., 1997; Peñaranda-Carrillo

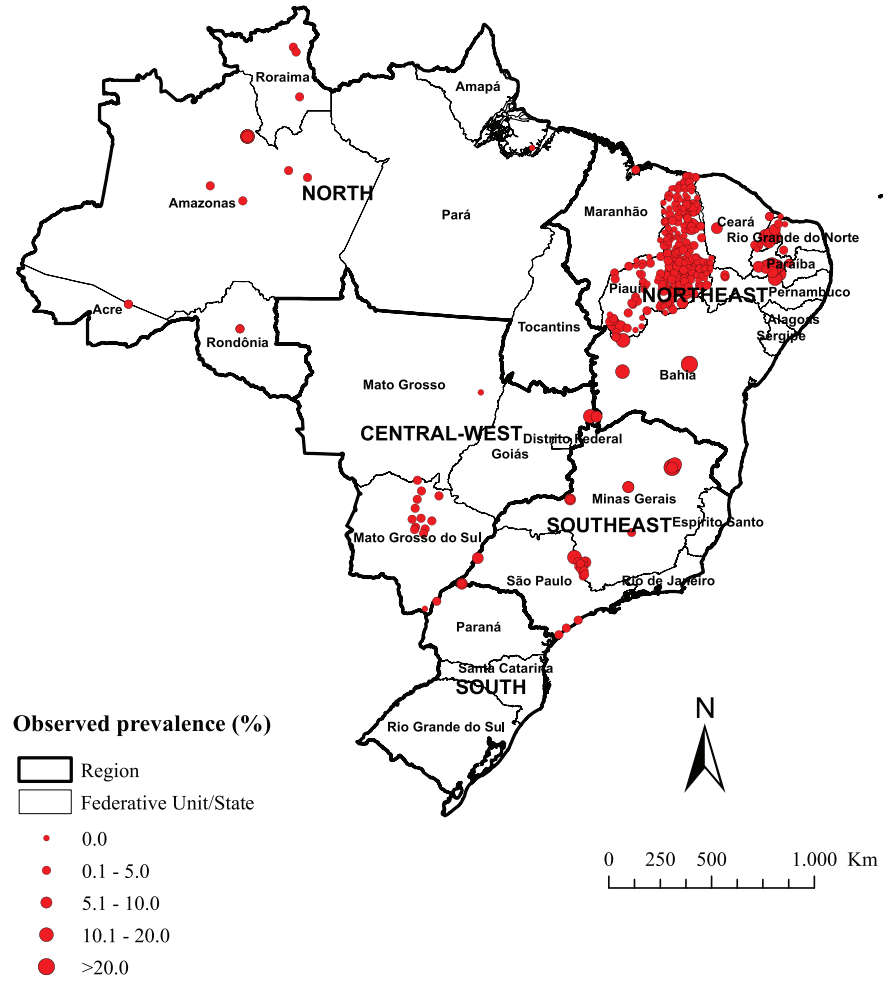

Fig. 2. Spatial distribution of observed Chagas disease prevalence in populationbased surveys.

et al., 2002; Pereira and Coura, 1986; Pereira and Coura, 1987; Silva et al., 2009; Silva et al., 2010; Silva and Goldenberg, 2008; Tachibana et al., 1999; Valente et al., 1998) (Fig. 1). These included a total of 125,580 individuals, with 5229 cases (4.2\%) of $T$. cruzi infection.

\subsection{Characteristics of studies}

The studies were conducted between 1980 and 2011 in 18 Brazilian states. The majority was conducted in the Northeast region (42.9\%). Most data were collected in the 1990s and after 2000 (38.1\%), and were from rural areas (47.6\%). The sample size ranged from 73 to 36,399 individuals (mean: 2990; standard deviation [SD \pm ]: 6679; median: 684.5). The combination of two or more different serological tests for the diagnosis of $T$. cruzi infection was used in $64.3 \%$ of studies. Prevalence of Chagas disease varied from $0 \%$ to $25.1 \%$. Detailed characteristics of the included studies on the prevalence of Chagas disease are presented in Appendix A.

\subsection{Geographical and temporal distribution of study sites}

A total of 319 study sites were identified; 310 were unique survey locations, most of them in Piauí state in the northeast of the country. Spatial distribution and observed prevalence by location are depicted in Fig. 2.

An overview of the identified surveys with relevant Chagas disease prevalence data is presented in Table 1. Most studies were performed in the Northeast region. Some states contain a large number of survey locations, while from other states no Chagas disease surveys were published. Most of the surveys were done after 2000. Distribution of surveys within the different time periods ranged from state to state. While some states only have surveys for one or two periods, other states are well covered over time.

The mean prevalence was $4.2 \%$ (95\% CI: $4.1-4.3$ ) for the entire period. In the $1980 \mathrm{~s}$, prevalence was $4.0 \%$ (95\% CI: $3.8-4.2$ ), $7.0 \%$ 
Table 1

Overview of Chagas disease prevalence data included in the analysis.

\begin{tabular}{|c|c|c|c|c|c|c|c|c|c|}
\hline \multirow[t]{3}{*}{ Region/State } & \multicolumn{2}{|c|}{ Number of locations } & \multicolumn{6}{|c|}{ Survey period } & \multirow{3}{*}{$\begin{array}{l}\text { Prevalence (\%) } \\
\text { Mean (CI 95\%) }\end{array}$} \\
\hline & \multirow[t]{2}{*}{ Total } & \multirow[t]{2}{*}{ Unique } & \multicolumn{2}{|c|}{ 1980-1989 } & \multicolumn{2}{|c|}{ 1990-1999 } & \multicolumn{2}{|c|}{$>2000$} & \\
\hline & & & $n$ & Prevalence \% (95\% CI) & $n$ & Prevalence \% (95\% CI) & $n$ & Prevalence \% (95\% CI) & \\
\hline North region & 15 & 12 & - & - & 5 & $9.9(8.6-11.3)$ & 10 & $2.1(1.8-2.5)$ & $4.2(3.7-4.7)$ \\
\hline Acre & 2 & 2 & - & - & - & - & 2 & $0.8(0.4-1.6)$ & $0.8(0.3-1.6)$ \\
\hline Rondônia & 2 & 1 & - & - & - & - & 2 & $1.6(0.6-3.2)$ & $1.6(0.6-3.2)$ \\
\hline Amazonas & 7 & 5 & - & - & 3 & $11.4(9.9-13.0)$ & 4 & $3.5(2.7-4.3)$ & $7.0(6.2-7.8)$ \\
\hline Roraima & 3 & 3 & - & - & - & - & 3 & $1.4(0.9-2.0)$ & $1.4(0.9-2.0)$ \\
\hline Pará & 1 & 1 & - & - & 1 & $0.0(0.0-1.4)$ & - & - & $0.0(0.0-1.4)$ \\
\hline Amapá & - & - & - & - & - & - & - & - & - \\
\hline Tocantins & - & - & - & - & - & - & - & - & - \\
\hline Northeast region & 260 & 257 & 15 & $8.7(8.1-9.3)$ & 9 & $10.1(9.2-11.0)$ & 236 & $2.5(2.4-2.7)$ & $4.0(3.8-4.2)$ \\
\hline Maranhão & 1 & 1 & 1 & $4.6(2.7-7.2)$ & - & - & - & - & $4.6(2.7-7.2)$ \\
\hline Piauí & 222 & 219 & 4 & $14.0(11.9-16.4)$ & 1 & $14.3(10.3-19.1)$ & 217 & $2.3(2.2-2.5)$ & $2.7(2.5-2.9)$ \\
\hline Ceará & 3 & 3 & - & - & 1 & $5.7(4.8-6.7)$ & 2 & $1.9(1.3-2.6)$ & $4.2(3.6-4.8)$ \\
\hline Rio Grande do Norte & 16 & 16 & - & - & - & - & 16 & $5.9(5.0-7.0)$ & $5.9(5.0-7.0)$ \\
\hline Paraíba & 9 & 9 & 9 & $8.1(7.4-8.8)$ & - & - & 1 & $1.4(0.3-4.0)$ & $7.8(7.2-8.5)$ \\
\hline Pernambuco & 6 & 6 & - & - & 6 & $9.1(7.2-11.2)$ & - & - & $9.1(7.2-11.2)$ \\
\hline Alagoas & - & - & - & - & - & - & - & - & - \\
\hline Sergipe & - & - & - & - & - & - & - & - & - \\
\hline Bahia & 2 & 2 & 1 & $11.0(7.9-14.8)$ & 1 & $25.1(21.9-28.5)$ & - & - & $20.4(18.0-23.0)$ \\
\hline Southeast region & 27 & 27 & 16 & $2.9(2.8-3.1)$ & 7 & $12.4(11.5-13.3)$ & 4 & $2.8(1.9-3.9)$ & $4.1(3.9-4.3)$ \\
\hline Minas Gerais & 8 & 8 & 1 & $12.6(1.8-19.9)$ & 6 & $13.6(12.5-14.1)$ & 1 & $2.1(1.1-3.5)$ & $12.1(11.3-12.9)$ \\
\hline Espírito Santo & - & - & - & - & - & - & - & - & - \\
\hline Rio de Janeiro & - & - & - & - & - & - & - & - & - \\
\hline São Paulo & 19 & 19 & 15 & $2.1(2.0-2.3)$ & 1 & $10.1(8.8-11.5)$ & 3 & $3.9(2.3-6.2)$ & $2.6(2.4-2.8)$ \\
\hline South region & 1 & 1 & - & - & - & - & 1 & $2.0(0.5-7.6)$ & $2.0(0.5-7.6)$ \\
\hline Paraná & 1 & 1 & - & - & - & - & 1 & $2.0(0.5-7.6)$ & $2.0(0.5-7.6)$ \\
\hline Santa Catarina & - & - & - & - & - & - & - & - & - \\
\hline Rio Grande do Sul & & & & - & - & - & - & - & - \\
\hline Central-West region & 16 & 16 & - & - & 15 & $4.7(4.4-5.0)$ & 1 & $0.0(0.0-4.9)$ & $4.7(4.4-5.0)$ \\
\hline Mato Grosso & 1 & 1 & - & - & 1 & $0.0(0.0-2.2)$ & - & - & $0.0(0.0-2.2)$ \\
\hline Mato Grosso do Sul & 16 & 16 & - & - & 12 & $1.8(1.6-2.1)$ & 1 & $0.0(0.0-4.9)$ & $1.8(1.6-2.1)$ \\
\hline Goiás & 2 & 2 & - & - & 2 & $12.3(11.5-13.2)$ & - & - & $12.3(11.5-13.2)$ \\
\hline Distrito Federal & - & - & - & - & - & - & - & - & - \\
\hline Total Brazil & 319 & 310 & 31 & $4.0(3.8-4.2)$ & 36 & $7.0(6.7-.7 .3)$ & 252 & $2.5(2.3-2.6)$ & $4.2(4.1-4.3)$ \\
\hline
\end{tabular}

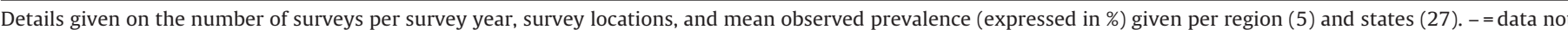
found or not applicable because there were no relevant papers for this region/state. $95 \% \mathrm{CI}$ : $95 \%$ confidence intervals calculated using exact binomial method.

(95\% CI: 6.7-7.3) in the 1990s, and 2.5\% (95\% CI: 2.3-2.6) after 2000. The mean prevalence ranged between states, from 2.1\% (São Paulo) to $14.0 \%$ (Piauí) in the 1980 s, and $0 \%$ (Pará and Mato Grosso) and $25.1 \%$ (Bahia) in the 1990s, and between 0\% (Mato Grosso do Sul) and 5.9\% (Rio Grande do Norte) after 2000

\subsection{Overall prevalence of Chagas disease}

Pooled prevalence estimates for the 42 studies included in the meta-analysis are presented in Table 2. Substantial heterogeneity was observed in most pooled estimates, which remained even after subgroup analysis $\left(I^{2}>75 \%\right.$ and $\left.p<0.001\right)$. The pooled estimate of Chagas disease prevalence across studies for the entire period was $4.2 \%$ (95\% CI: 3.1-5.7), ranging from $4.4 \%$ (95\% CI: $2.3-8.3$ ) in the 1980s, $7.2 \%$ (95\% CI: 4.6-11.0) in the 1990 s, to 2.4 (95\% CI: $1.5-3.8$ ) after 2000 . Sub-analysis by geographical region revealed wide variations in prevalence. The highest estimated regional prevalence was 5.0\% (95\% CI: 3.1-8.1) in the Northeast and 5.0\% (95\% CI: 2.4-9.9) in the Southeast region.

Information about sex distribution was available for 19 studies. Prevalence estimates were slightly higher for females $(4.2 \%$; $95 \% \mathrm{CI}$ : 2.6-6.8) than for males (4.1\%; 95\% CI: 2.6-6.6). In general, prevalence was higher in advanced age groups. The highest prevalence of $17.7 \%$ (95\% CI: $11.4-26.5$ ) was found in the $>60$ age group, while the lowest (1.1\%; 95\% CI: 0.5-2.4) in the 0-9 year-olds.

Pooled Chagas disease prevalence was higher in surveys conducted in mixed urban/rural locations (6.4\%; 95\% CI: 4.2-9.4) and with sample sizes of 500-1000 individuals (6.8\%; 95\% CI: 4.2-10.9). The pooled prevalence of studies conducted exclusively in urban areas was $6.0 \%$ (95\% CI: 3.0-11.4).

Using the population data of the 2010 National Population Census (190.8 million people) and extrapolating our findings to the Brazilian general population, we estimated that in 2010 there were about 4.6 million (95\% CI: 2.9-7.2 million) of people infected with T. cruzi in Brazil.

\section{Discussion}

We performed the first systematic nationwide assessment of Chagas disease prevalence in the last three decades. We describe prevalence estimates in Brazil derived from available populationbased data. The data evidence high prevalence in endemic regions, especially in urban areas and the elderly. Chagas disease prevalence varied over time, with lowest levels since 2000.

Currently, only acute cases of Chagas disease are of compulsory notification in Brazil, and there are no nationwide data on the magnitude of the disease (Martins-Melo et al., 2012b; Ramos Jr. et al., 2010; Ramos Jr. and Carvalho, 2009). Thus, analysis of population-based studies at both national and regional level is needed to estimate the magnitude of the disease and to describe areas of active transmission (Camargo et al., 1984; Ostermayer et al., 2011; Passos and Silveira, 2011; Silveira, 2011b; Silveira et al., 2011). The only nationwide survey of prevalence of Chagas disease in the Brazilian rural general population was conducted between 
Table 2

Pooled prevalence estimates of Chagas disease, stratified by subgroups.

\begin{tabular}{|c|c|c|c|c|c|c|c|c|}
\hline \multirow[t]{2}{*}{ Characteristics } & \multirow[t]{2}{*}{ Number of studies } & \multirow[t]{2}{*}{ Range $^{a}$} & \multicolumn{4}{|c|}{ Pooled Chagas' disease prevalence } & \multicolumn{2}{|c|}{ Heterogeneity } \\
\hline & & & Case & Population & Prevalence (\%) & $95 \% \mathrm{CI}$ & $I^{2}(\%)$ & $P$-value (Cochran's $Q$ ) \\
\hline Overall prevalence & 42 & $0.0-25.1$ & 5229 & 125,580 & 4.2 & $3.1-5.7$ & 99.1 & $<0.001$ \\
\hline $\begin{array}{l}\text { Survey period } \\
1980-1989 \\
1990-1999 \\
>2000\end{array}$ & $\begin{array}{l}10 \\
16 \\
16\end{array}$ & $\begin{array}{l}0.6-21.7 \\
0.0-25.1 \\
0.0-9.9\end{array}$ & $\begin{array}{l}1746 \\
2261 \\
1222\end{array}$ & $\begin{array}{l}43,993 \\
32,185 \\
49,402\end{array}$ & $\begin{array}{l}4.4 \\
7.2 \\
2.4\end{array}$ & $\begin{array}{l}2.3-8.3 \\
4.6-11.0 \\
1.5-.3 .8\end{array}$ & $\begin{array}{l}99.3 \\
98.9 \\
97.5\end{array}$ & $\begin{array}{l}<0.001 \\
<0.001 \\
<0.001\end{array}$ \\
\hline $\begin{array}{l}\text { Sex } \\
\text { Male } \\
\text { Female }\end{array}$ & $\begin{array}{l}19 \\
19\end{array}$ & $\begin{array}{l}0.0-27.0 \\
0.0-25.9\end{array}$ & $\begin{array}{l}1421 \\
2139\end{array}$ & $\begin{array}{l}41,132 \\
48,214\end{array}$ & $\begin{array}{l}4.1 \\
4.2\end{array}$ & $\begin{array}{l}2.6-6.6 \\
2.6-6.8\end{array}$ & $\begin{array}{l}98.5 \\
99.0\end{array}$ & $\begin{array}{l}<0.001 \\
<0.001\end{array}$ \\
\hline $\begin{array}{l}\text { Age group (years) } \\
0-9 \\
10-19 \\
20-29 \\
30-39 \\
40-49 \\
50-59 \\
\geq 60\end{array}$ & $\begin{array}{l}19 \\
20 \\
20 \\
19 \\
19 \\
18 \\
19\end{array}$ & $\begin{array}{l}0.0-17.1 \\
0.0-15.4 \\
0.0-24.6 \\
0.0-33.3 \\
0.0-45.8 \\
1.2-58.8 \\
0.0-66.7\end{array}$ & $\begin{array}{l}176 \\
293 \\
321 \\
635 \\
798 \\
781 \\
924\end{array}$ & $\begin{array}{r}22,180 \\
22,735 \\
14,339 \\
11,308 \\
8604 \\
6528 \\
8052\end{array}$ & $\begin{array}{r}1.1 \\
1.6 \\
3.5 \\
7.2 \\
11.9 \\
17.5 \\
17.7\end{array}$ & $\begin{array}{c}0.5-2.4 \\
0.8-3.1 \\
1.9-6.4 \\
4.6-12.6 \\
7.3-18.7 \\
11.1-26.3 \\
11.4-26.5\end{array}$ & $\begin{array}{l}95.6 \\
95.9 \\
95.8 \\
97.8 \\
97.2 \\
97.0 \\
97.5\end{array}$ & $\begin{array}{l}<0.001 \\
<0.001 \\
<0.001 \\
<0.001 \\
<0.001 \\
<0.001 \\
<0.001\end{array}$ \\
\hline $\begin{array}{l}\text { Region of Brazil } \\
\text { North } \\
\text { Northeast } \\
\text { Southeast } \\
\text { Central-West } \\
\text { South }\end{array}$ & $\begin{array}{r}10 \\
18 \\
9 \\
4 \\
1\end{array}$ & $\begin{array}{c}0.0-13.7 \\
0.6-25.1 \\
1.3-18.5 \\
0.0-12.7 \\
-\end{array}$ & $\begin{array}{r}311 \\
2183 \\
1768 \\
965 \\
2\end{array}$ & $\begin{array}{r}7435 \\
54,701 \\
42,752 \\
20,592 \\
100\end{array}$ & $\begin{array}{l}2.9 \\
5.0 \\
5.0 \\
2.2 \\
2.0\end{array}$ & $\begin{array}{l}1.5-5.8 \\
3.1-8.1 \\
2.4-9.9 \\
0.4-14.5 \\
0.5-7.6\end{array}$ & $\begin{array}{r}96.6 \\
99.1 \\
99.5 \\
99.6 \\
0.0\end{array}$ & $\begin{array}{l}<0.001 \\
<0.001 \\
<0.001 \\
<0.001 \\
1\end{array}$ \\
\hline $\begin{array}{l}\text { Survey area } \\
\text { Rural } \\
\text { Urban } \\
\text { Urban/Rural } \\
\text { Peri-urban } \\
\text { NS }\end{array}$ & $\begin{array}{r}20 \\
7 \\
10 \\
1 \\
4\end{array}$ & $\begin{array}{c}0.0-21.7 \\
1.8-13.7 \\
0.8-25.1 \\
- \\
0.6-11.0\end{array}$ & $\begin{array}{r}2000 \\
1282 \\
1671 \\
13 \\
258\end{array}$ & $\begin{array}{r}80,208 \\
24,760 \\
15,480 \\
1076 \\
3668\end{array}$ & $\begin{array}{l}3.2 \\
6.0 \\
6.4 \\
1.2 \\
4.7\end{array}$ & $\begin{array}{l}2.1-4.8 \\
3.0-11.4 \\
4.2-9.4 \\
0.7-2.1 \\
2.2-10.0\end{array}$ & $\begin{array}{r}98.4 \\
99.2 \\
98.0 \\
0.0 \\
95.0\end{array}$ & $\begin{array}{c}<0.001 \\
<0.001 \\
<0.001 \\
1 \\
<0.001\end{array}$ \\
\hline $\begin{array}{l}\text { Sample size } \\
<100 \\
100-499 \\
500-1000 \\
>1000\end{array}$ & $\begin{array}{r}2 \\
13 \\
11 \\
16\end{array}$ & $\begin{array}{l}0.0-3.0 \\
0.0-14.3 \\
0.6-25.1 \\
0.8-18.5\end{array}$ & $\begin{array}{r}3 \\
147 \\
702 \\
4377\end{array}$ & $\begin{array}{r}172 \\
3444 \\
7567 \\
125,192\end{array}$ & $\begin{array}{l}2.4 \\
3.1 \\
6.8 \\
4.0\end{array}$ & $\begin{array}{l}0.9-6.7 \\
1.8-.5 .2 \\
4.2-10.9 \\
2.5-9.4\end{array}$ & $\begin{array}{r}0.0 \\
87.8 \\
97.3 \\
99.6\end{array}$ & $\begin{array}{r}0.321 \\
<0.001 \\
<0.001 \\
<0.001\end{array}$ \\
\hline $\begin{array}{l}\text { Serological test } \\
\text { IFA } \\
\text { IFA/IHA } \\
\text { IHA/ELISA } \\
\text { ELISA/IFA } \\
\text { ELISA/IFA/IHA }\end{array}$ & $\begin{array}{r}15 \\
2 \\
1 \\
15 \\
9\end{array}$ & $\begin{array}{c}0.0-21.7 \\
5.7-11.0 \\
- \\
0.0-18.5 \\
0.8-25.1\end{array}$ & $\begin{array}{r}2707 \\
178 \\
14 \\
723 \\
1607\end{array}$ & $\begin{array}{r}83,631 \\
2794 \\
675 \\
8978 \\
29,502\end{array}$ & $\begin{array}{l}3.8 \\
7.9 \\
2.1 \\
3.8 \\
5.1\end{array}$ & $\begin{array}{l}2.2-6.4 \\
4.1-14.7 \\
1.2-3.5 \\
2.3-6.4 \\
2.6-9.7\end{array}$ & $\begin{array}{r}99.4 \\
92.8 \\
0.0 \\
96.6 \\
99.3\end{array}$ & $\begin{array}{c}<0.001 \\
<0.001 \\
1 \\
<0.001 \\
<0.001\end{array}$ \\
\hline
\end{tabular}

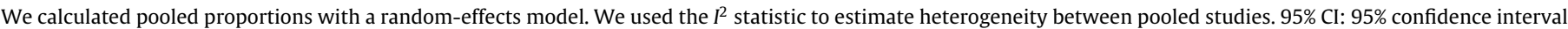
IFA: indirect immunofluorescence assay; ELISA: enzyme-linked immunosorbent assay; IHA: indirect hemagglutination; NS: not specified.

a Observed prevalence in studies.

b Standardization of age groups and sex utilized in some studies.

1975 and 1980, which estimated an overall prevalence of $4.2 \%$, corresponding to 6.5 million infected people (Camargo et al., 1984; Silveira et al., 2011).

To evaluate the impact of control measures and to estimate the importance of congenital transmission of $T$. cruzi infection, recently (2001-2008) a new national survey with children from 0 to 5 years of age was conducted, with a prevalence of $0.03 \%$. This low prevalence in preschool children indicates control of transmission by the main vector (Triatoma infestans) in Brazil (Ostermayer et al., 2011). In fact, the proportion of new cases of Chagas disease has been dramatically reduced in the last 30 years, due to systematic surveillance and control in endemic areas in Brazil (Ramos Jr. et al., 2010; Silveira, 2011a; Silveira and Dias, 2011). Occasionally, there was a trend of ageing of patients with Chagas disease, with the highest prevalence and mortality verified in more advanced age groups (Martins-Melo et al., 2012c,e). This transition can be explained mainly due to a cohort effect, a consequence of exposure to T. cruzi infection in the past (Lima-Costa et al., 2004). The increased survival of individuals with Chagas disease will pose health professionals to other challenges, due to the association and interaction with other chronic diseases, such as hypertension and diabetes mellitus
(Martins-Melo et al., 2012a,e). Additionally, it broadens the possibility of association with HIV infection or other immunosuppressive conditions (e.g., transplantation), with the potential reactivation of Chagas disease (Almeida et al., 2011; Martins-Melo et al., 2012c).

Our study indicates that the persisting Chagas disease prevalence in some endemic areas reflects the need of sustainability of control programmes, avoiding a recrudescence of the vector transmission of disease (Abad-Franch et al., 2013; Ramos Jr. and Carvalho, 2001). There was a high prevalence in some studies performed in the Amazon region, an area previously considered non-endemic (Barata et al., 1988). Currently, this region is responsible for the largest amount of cases of acute Chagas' disease, mainly by oral transmission through the consumption of natural products such as the palm products of açaí juice, juçara juice and bacaba (Dias and Amato Neto, 2011; PAHO, 2009). This mode of transmission and emerging public health concerns for safe foods, encourage surveillance activities aimed at pasteurizing the products and controlling the export of untreated juice and other products to other regions and out of the country (Dias and Amato Neto, 2011; PAHO, 2009). In fact, the main forms of 
transmission of $T$. cruzi infection, vectorial and transfusional, are controlled (Moraes-Souza and Ferreira-Silva, 2011; Silveira and Dias, 2011). With the strengthening of the control programmes in Brazil, transmission via the main domiciliary vector ( $T$. infestans) was controlled and almost $100 \%$ of blood donors are screened serologically (Massad, 2008). The transmission control reduced substantially the number of new cases and deaths from Chagas disease in endemic areas (Martins-Melo et al., 2012a; Ramos Jr. et al., 2010; Silveira, 2011a). Currently, the majority of reported cases of acute Chagas disease in Brazil are caused by oral transmission (Silveira, 2011a).

The decrease of Chagas disease prevalence over the past years is also related to campaigns against Chagas disease on the American Continent by the World Health Organization (WHO) and the Pan American Health Organization (PAHO). These initiatives were performed in cooperation with regional national authorities since the 1990s, such as the creation of the Initiative of Southern Cone countries (Moncayo and Silveira, 2009; WHO, 2010).

Changes in the incidence, prevalence and mortality are also consequences of improvements of socio-economic conditions and migration (Moncayo and Silveira, 2009; Dias, 2013). Over many years, Chagas disease was considered a health problem in endemic rural areas of Latin America (Coura and Borges-Pereira, 2010; Moncayo and Silveira, 2009). The rural-urban migration in recent decades displaced millions of infected people to urban areas, where vector transmission does not occur, causing a change in the epidemiological pattern of Chagas disease. The disease has been transformed into an urban infection that can also be transmitted through blood transfusion and congenital route (Moncayo and Silveira, 2009; Silveira, 2011a). In Brazil, it is estimated that about $70-90 \%$ of people affected by Chagas disease are now living in urban areas (Dias, 2007), which is reflected in our study by the fact that high prevalences were observed in surveys conducted in urban areas.

Blood transfusion was the main mechanism of dissemination of the disease in endemic areas along the 1980s and 1990s (Moraes-Souza and Ferreira-Silva, 2011). High prevalence of Chagas disease in urban centres and the inexistence of control programmes resulted in the 1970s in about 20,000 new cases annually in Brazil by transfusion transmission of $T$. cruzi (Moraes-Souza and FerreiraSilva, 2011). Improved coverage of screening of blood donors substantially reduced the rate of blood-borne transmission (Dias and Amato Neto, 2011; Moraes-Souza and Ferreira-Silva, 2011). Congenital transmission still occurs at considerable levels in Brazil, except in the state of Rio Grande do Sul, which has the largest rate of vertical transmission, as indicated by data collected in a recent survey on seroprevalence in children under five years of age (Ostermayer et al., 2011).

Chagas disease is mainly enzootic hindering elimination and is a major threat to re-introduction in regions where control has been achieved (Coura and Borges-Pereira, 2010). Furthermore, there is no vaccine available to prevent the disease and, although acute infections can be treated, the lack of symptoms during the acute phase leads to delayed diagnosis and makes the epidemiological surveillance a difficult routine (Bwititi and Browne, 2012). Thus, control of Chagas disease remains a challenge for public health, and probably will remain so for many years (Abad-Franch et al., 2013; Massad, 2008; Ramos Jr. and Carvalho, 2001). New control strategies for oral transmission (in the Amazon region) and secondary vectors such as Triatoma brasiliensis and Triatoma pseudomaculata (in the Northeast region) must be implemented and assessed systematically (Martins-Melo et al., 2012a; Massad, 2008). In addition, adequate access to health services and social assistance should be guaranteed for the large number of individuals afflicted with chronic Chagas disease during the last decades (Ramos Jr. and Carvalho, 2009).
Our study has some limitations. First, data showed a large degree of heterogeneity among studies, and the findings do not necessarily reflect the real situation of the entire country. There is clearly not yet sufficient evidence to estimate Chagas disease prevalence in the general population at national level, and additional populationbased studies are needed. The studies were conducted mainly in endemic areas for Chagas disease and were under-represented in others. The regional differences of data availability may have led to an overestimation of the estimates and precluded a more thorough analysis. An alternative would be the use of more robust statistical methods, such as Bayesian geostatistical models (Diggle et al., 1998), that combine disease data with sociodemographic and environmental data to predict risk, and extrapolate the burden of infection, even in regions where there are few data (Chammartin et al., 2013). This was verified in studies with schistosomiasis data in Africa (Schur et al., 2011; Schur et al., 2013) and soil-transmitted helminthiases in South America (Chammartin et al., 2013). However, due to the heterogeneous distribution of Chagas' disease in Brazil, the model must take into consideration socio-demographic and environmental factors, distribution of vectors and reservoirs, human migration and level of the human action on nature (Dias, 2007; Dias et al., 2002c).

Other limitations are a consequence of incomplete or inaccurate information provided in the publications. For example, many studies did not stratify data by sex and age groups were not stratified in a standardized manner. Despite a comprehensive search, it is likely that some studies conducted have not been found because they are not published in indexed journals, and consequently end up not being cited by other authors. Non-publication bias may have caused an overestimation of prevalences. In addition, studies were conducted between 1980 and 2012. This long time period was necessary because of the limited availability of data on in some areas in Brazil, but limits interpretation to some degree. There were also variations of diagnostic tests used in different studies. Despite the predominance of the use of the combination of two or more test to confirm the diagnosis of chronic Chagas disease according to standard of the WHO/PAHO, some studies used only one diagnostic test.

Despite the discussed limitations, the results of this study clearly call to action on research and surveillance of Chagas disease in Brazil. There is an urgent need to conduct national and regional surveys of seroprevalence in order to obtain more reliable information, and to identify high risk areas. However, interruption of transmission by its main domestic vectors reduced political interest and operational budgets (Massad, 2008), and the need for continued surveillance and intervention becomes less appreciated at the political level. There is also a general tendency to underestimate potential re-emergence of vector-borne and emerging infections (Dias et al., 2002b).

Acute Chagas disease is often asymptomatic and not diagnosed and notified. This naturally weakens the surveillance system, reinforcing further the impression that the transmission does not occur (Abad-Franch et al., 2013). The Ministry of Health of Brazil has been discussing the possibility of compulsory notification of chronic forms (Martins-Melo et al., 2012a), considering the burden of chronic diseases in the country and the fact that reactivation of Chagas disease in the presence of HIV infection is considered an AIDS-defining condition in Brazil (Ramos Jr., 2004). This study provides further evidence for the need for introduction of chronic forms as notifiable disease.

\section{Conclusions}

Despite interruption of main vector and blood-borne transmission, considerable Chagas disease prevalence is observed in 
Brazil's endemic areas, with declines in the last decades. The infected population is ageing and increasingly urbanized. Systematic population-based studies at regional and national level are needed to provide more accurate estimates, identify high risk areas and to plan and assess systematic control measures in Brazil.

\section{Acknowledgements}

This study received financial support from the Brazilian Swiss Joint Research Programme (BSJRP 011008). JH is a research fellow at the Conselho Nacional de Desenvolvimento Científico e Tecnológico (CNPq). We thank CNPq (Process: 238926/2012-5) for providing PhD sandwich scholarship and the Fundação Coordenação de Aperfeiçoamento de Pessoal de Nível Superior (CAPES) for granting a PhD scholarship to FRM. The authors are grateful to Penelope Vounatsou, Frédérique Chammartin and Erika Langer for the technical collaboration and assistance during this study.

\section{Appendix A. Supplementary data}

Supplementary data associated with this article can be found, in the online version, at http://dx.doi.org/10.1016/j. actatropica.2013.10.002.

\section{References}

Abad-Franch, F., Diotaiuti, L., Gurgel-Gonçalves, R., Gürtler, R.E., 2013. Certifying the interruption of Chagas disease transmission by native vectors: cui bono? Mem. Inst. Oswaldo Cruz 108, 251-254.

Akhavan, D., 2000. Cost-effectiveness Analysis of the Project for Controlling Chagas Disease in Brazil-Final Report. Pan American Health Organization, Brasília.

Almeida, E.A., Ramos Jr., A.N., Correia, D., Shikanai-Yasuda, M.A., 2011. Co-infection Trypanosoma cruzi/HIV: systematic review (1980-2010). Rev. Soc. Bras. Med. Trop. 44, 762-770.

Aras, R., Veiga, M., Gomes, I., Mota, G., Rodrigues, B., Rabelo, R., et al., 2002. Prevalence of Chagas' disease in Mulungu do Morro northeastern Brazil. Arq. Bras. Cardiol. $78,441-443$

Arruda Jr., E.R., Silva, S.M., Mendonça, M.Z.G., Barros, M.A., 1984. Chagas' disease. Epidemiological study in the municipality of Santana dos Garrotes, Piancó Valley. Human and triatomine serologycal survey. CCS 6, 43-46.

Barata, J.M.S., Rocha, R.M., Rodrigues, V.L.C., Ferraz Filho, A.N., 1988. The first autochthonous case of American trypanosomiasis in the State of Acre, Brazil, and its correlation with the strains identified in the human case and the sylvatic triatomines in the area. Rev. Saude Publica 22, 401-410.

Bento, D.N., Branco, A., Freitas, M., Pinto, A., 1984. Epidemiologic studies of Chagas' disease in the urban zone of Teresina, State of Piaui, Northeastern Brazil. Rev. Soc. Bras. Med. Trop. 17, 199-203.

Bento, D.N., Freitas, M., Pinto, A.S., 1989. Epidemiology of Chagas disease in the municipalities of Castelo do Piaui and Pedro II, state of Piaui, Brazil. Rev. Soc. Bras. Med. Trop. 22, 73-79.

Bento, D.N., Farias, L.M., Godoy, M.F., Araujo, J.F., 1992. The epidemiology of Chagas' disease in a rural area of the city of Teresina, Piaui, Brazil. Rev. Soc. Bras. Med. Trop. 25, 51-58.

Bezerra, J.M., Nascimento, M.D.S., Ribeiro, M.L.J.F., Oliveira, O.S., Mendonça, J.R., 1983. Serologic evaluation of Chagas' disease and Leishmaniosis in adult population of Säo Luís-MA-Brazil. Rev. Patol. Trop. 12, 145-150.

Boia, M.N., da Motta, L.P., Salazar, M.D., Mutis, M.P., Coutinho, R.B., Coura, J.R., 1999 Cross-sectional study of intestinal parasites and Chagas' disease in the Municipality of Novo Airao, State of Amazonas, Brazil. Cad. Saude Publica 15, 497-504.

Borges-Pereira, J., Zauza, P.L., Galhardo, M.C., Nogueira, J., Pereira, G.R., Cunha, R.V. 2001. Chagas' disease in a urban population of the health district of Rio Verde, Mato Grosso do Sul State, Brazil. Rev. Soc. Bras. Med. Trop. 34, 459-466.

Borges-Pereira, J., Castro, J.A., Campos, J.H., Nogueira Jde, S., Zauza, P.L., Marques, P., et al., 2002. Study of the infection and morbidity of Chagas' disease in municipality of Joao Costa: National Park Serra da Capivara, Piaui, Brazil. Rev. Soc. Bras. Med. Trop. 35, 315-322.

Borges-Pereira, J., Castro, J.A., da Silva, A.G., Zauza, P.L., Bulhoes, T.P., Goncalves, M.E., et al., 2006. Seroprevalence of Chagas disease infection in the State of Piaui, 2002. Rev. Soc. Bras. Med. Trop. 39, 530-539.

Borges-Pereira, J., Sarquis, O., Zauza, P.L., Britto, C., Lima, M.M., 2008. Epidemiology of Chagas disease in four rural localities in Jaguaruana, State of Ceara: seroprevalence of infection, parasitemia and clinical characteristics. Rev. Soc. Bras. Med. Trop. 41, 345-351.

Brito, C.R.N., Sampaio, G.H.F., Câmara, A.C.J., Nunes, D.F., Azevedo, P.R.M., Chiari, E., et al., 2012. Seroepidemiology of Trypanosoma cruzi infection in the semiarid rural zone of the State of Rio Grande do Norte, Brazil. Rev. Soc. Bras. Med. Trop. $45,346-352$.
Bwititi, P., Browne, J., 2012. Seroprevalence of Trypanosoma cruzi in blood donors at the National Blood Transfusion Services: Guyana. West Indian Med. J. 61, 559-563.

Camargo, M.E., Silva, G.R., Castilho, E.A., Silveira, A.C., 1984. Serological survey of the prevalence of Chagas' infection in Brazil, 1975/1980. Rev. Inst. Med. Trop. Sao Paulo 26, 192-204.

Carvalho, E.O., Rosa, J.A., Carvalho, A.A., Chaves, H.C., Souza, E.A., Ostermayer, A.L. et al., 2011a. Study on Chagas disease occurrence in the municipality of Monte Negro, State of Rondonia, Brazilian Amazon. Rev. Soc. Bras. Med. Trop. 44, 703-707.

Carvalho, M.E., da Silva, R.A., Barata, J.M., Domingos Mde, F., Ciaravolo, R.M. Zacharias, F., 2003. Chagas' disease in the southern coastal region of Brazil. Rev. Saude Publica 37, 49-58.

Carvalho, M.E., Silva, R.A., Wanderley, D.M., Barata, J.M., 2011b. Chagas disease Control Program in the State of Sao Paulo, Brazil: seroepidemiological aspects of homogeneous geographic microregions. Rev. Soc. Bras. Med. Trop. 44 (Suppl. 2), 85-94.

Chammartin, F., Scholte, R.G., Guimarães, L.H., Tanner, M., Utzinger, J., Vounatsou, P., 2013. Soil-transmitted helminth infection in South America: a systematic review and geostatistical meta-analysis. Lancet Infect. Dis. 13 $507-518$.

Coimbra Jr., C.E., Borges, M.M., Flowers, N.M., Santos, R.V., Piazza, R.F., 1992. Seroepidemiological survey for Chagas' disease among the Xavante Indians of central Brazil. Ann. Trop. Med. Parasitol. 86, 567-568.

Corrêa, N., Velásquez, L., Marques, J., Silva, A., 2011. Seroepidemiological study of leishmaniasis and Chagas disease in a rural community in the south of Mato Grosso do Sul-Brazil. Arq. Ciencias Saude UNIPAR 15, 23-28.

Coura, J.R., Naranjo, M.A., Willcox, H.P., 1995a. Chagas' disease in the Brazilian Amazon. II. A serological survey. Rev. Inst. Med. Trop. Sao Paulo 37, 103-107.

Coura, J.R., Willcox, H.P., Arboleda Naranjo, M., Fernandes, O., Paiva, D.D., 1995b. Chagas' disease in the Brazilian Amazon. III. A cross-sectional study (1). Rev. Inst. Med. Trop. Sao Paulo 37, 415-420.

Coura, J.R., Junqueira, A.C., Boia, M.N., Fernandes, O., Bonfante, C., Campos, J.E., et al., 2002. Chagas disease in the Brazilian Amazon: IV. A new cross-sectional study. Rev. Inst. Med. Trop. Sao Paulo 44, 159-165.

Coura, J.R., Borges-Pereira, J., 2010. Chagas disease: 100 years after its discovery. A systemic review. Acta Trop. 115, 5-13.

Dantas-Maia, T.O., Castro, C. Ostermayer, A.L. Macedo, V., 2007. Seroprevalence of American trypanosomiasis in adults in an area of the western Brazilian Amazon region. Rev. Soc. Bras. Med. Trop. 40, 436-442.

Dias, J.C., Machado, E.M., Borges, E.C., Moreira, E.F., Gontijo, C., Azeredo, B.V., 2002a Chagas' disease in Lassance, Minas Gerais State: clinical-epidemiological reevaluation ninety years after the discovery by Carlos Chagas. Rev. Soc. Bras. Med. Trop. 35, 167-176.

Dias, J.C., Silveira, A.C., Schofield, C.J., 2002b. The impact of Chagas disease control in Latin America: a review. Mem. Inst. Oswaldo Cruz 97, 603-612.

Dias, J.C., 2007. Globalization, inequity and Chagas disease. Cad. Saude Publica 23 (Suppl. 1), S13-S22.

Dias, J.C., Amato Neto, V., 2011. Prevention concerning the different alternative routes for transmission of Trypanosoma cruzi in Brazil. Rev. Soc. Bras. Med. Trop. 44 (Suppl. 2), 68-72.

Dias, J.C., Prata, A., Schofield C. 2002c. Chagas' disease in the Amazon: an overview of the current situation and perspectives for prevention. Rev. Soc. Bras. Med. Trop. 35, 669-678.

Dias, J.C., 2013. Human Chagas disease and migration in the context of globalization: some particular aspects. J. Trop. Med., 789758

Diggle, P.J., Tawn, J., Moyeed, R., 1998. Model-based geostatistics. Journal of the Royal Statistical Society: Series C (Applied Statistics) 47, 299-350.

Diotaiuti, L., Faria Filho, O.F., Carneiro, F.C., Dias, J.C., Pires, H.H., Schofield, C.J., 2000 Operational aspects of Triatoma brasiliensis control. Cad. Saude Publica 16 (Suppl. 2), 61-67.

Escolano, P., Liporaci, N., Manzan, C., Barbosa, A., Alves, V., Teixeira, R., et al., 1989. Prevalence of Chagas infection in Catolandia-Bahia. Rev. Soc. Bras. Med. Trop. 22, 159-160.

Figueredo-Silva, J., Kaneda, Y., Tachibana, H., Furushima, R., Tateno, S., Correia-Lima, F.G., et al., 1991. Epidemiological survey of Trypanosoma cruzi infection in northeastern Brazil using different diagnostic methods. Rev. Inst. Med. Trop. Sao Paulo 33, 193-198.

Fonsêca, D.V., Queiroz Vilar, A.C., Luna, C.M.B., 2012. Estudo soroepidemiológico da doença de Chagas no município de Salgadinho/PB. Biofar: Rev. Biol. Farm. 7 , 82-87.

Gascon, J., Bern, C., Pinazo, M.-J., 2010. Chagas disease in Spain, the United States and other non-endemic countries. Acta Trop. 115, 22-27.

Gazin, P., Melo, G., Abuquerque, A., Oliveira Jr., W., Soula, G., Audry, P., 2004 Chagas disease in a rural area of Northeast Brazil. Bull. Soc. Pathol. Exot. 97, 189-192.

Hedges, L.V., Vevea, J.L., 1998. Fixed- and random-effects models in meta-analysis. Psychol. Methods 3, 486-504.

Higgins, J.P.T., Thompson, S.G., Deeks, J.J., Altman, D.G., 2003. Measuring inconsistency in meta-analyses. BMJ 327, 557-560.

Huedo-Medina, T.B., Sanchez-Meca, J., Marin-Martinez, F., Botella, J., 2006. Assessing heterogeneity in meta-analysis: Q statistic or I-2 index? Psychol. Methods 11 , 193-206.

Lima-Costa, M.F., Peixoto, S.V., Giatti, L., 2004. Trends in mortality among older adults in Brazil (1980-2000). Epidemiol. Serv. Saude 13, 217-228. 
Lima, M.M., Sarquis, O., de Oliveira, T.G., Gomes, T.F., Coutinho, C., Daflon-Teixeira, N.F., et al., 2012. Investigation of Chagas disease in four periurban areas in northeastern Brazil: epidemiologic survey in man, vectors, non-human hosts and reservoirs. Trans. R. Soc. Trop. Med. Hyg. 106, 143-149.

Luitgards-Moura, J.F., Borges-Pereira, J., Costa, J., Zauza, P.L., Rosa-Freitas, M.G., 2005. On the possibility of autochthonous Chagas disease in Roraima, Amazon region, Brazil, 2000-2001. Rev. Inst. Med. Trop. Sao Paulo 47, 45-54.

Machado, E.R., Costa-Cruz, J.M., Gomes, S.B., 1998. Anti-Trypanosoma cruzi antibodies in the inhabitants of urban and rural areas of Abadia dos Dourados, State of Minas Gerais, Brazil. Rev. Inst. Med. Trop. Sao Paulo 40, 325-326.

Magalhães, B.M., Coelho, L.I., Maciel, M.G., Ferreira, J.M., Umezawa, E.S., Coura, J.R., et al., 2011. Serological survey for Chagas disease in the rural areas of Manaus, Coari, and Tefe in the Western Brazilian Amazon. Rev. Soc. Bras. Med. Trop. 44, 697-702.

Martins-Melo, F.R., Alencar, C.H., Ramos Jr., A.N., Heukelbach, J., 2012a. Epidemiology of mortality related to Chagas' disease in Brazil, 1999-2007. PLoS Negl. Trop. Dis. 6, e1508.

Martins-Melo, F.R., Ramos Jr., A.N., Alencar, C.H., Heukelbach, J., 2012b. Mortality due to Chagas disease in Brazil from 1979 to 2009: trends and regional differences. J. Infect. Dev. Ctries. 6, 817-824.

Martins-Melo, F.R., Ramos Jr., A.N., Alencar, C.H., Heukelbach, J., 2012c. Mortality related to Chagas disease and HIV/AIDS coinfection in Brazil. J. Trop. Med. 2012, 534649.

Martins-Melo, F.R., Ramos Jr., A.N., Alencar, C.H., Lange, W., Heukelbach, J., 2012d. Mortality of Chagas' disease in Brazil: spatial patterns and definition of high-risk areas. Trop. Med. Int. Health 17, 1066-1075.

Martins-Melo, F.R., Ramos Jr., A.N., Alencar, C.H., Heukelbach, J., 2012e. Multiple causes of death related to Chagas' disease in Brazil, 1999 to 2007. Rev. Soc. Bras. Med. Trop. 45, 591-596.

Martins-Melo, F.R., Heukelbach, J., 2013. Epidemiology and spatial distribution of mortality related to Chagas disease in Brazil, 1999 to 2007. Cad. Saude Col. 21, $105-106$.

Massad, E., 2008. The elimination of Chagas' disease from Brazil. Epidemiol. Infect. $136,1153-1164$

Massaro, D.C., Rezende, D.S., Camargo, L.M.A., 2008. Study of the triatomine fauna and occurrence of Chagas disease in Monte Negro, Rondonia, Brazil. Rev. Bras. Epidemiol. 11, 228-240.

Moncayo, A., Silveira, A.C., 2009. Current epidemiological trends for Chagas disease in Latin America and future challenges in epidemiology, surveillance and health policy. Mem. Inst. Oswaldo Cruz 104 (Suppl. 1), 17-30.

Montoya, R., Dias, J.C., Coura, J.R., 2003. Chagas disease in a community in southeast Brazil. I. A serologic follow-up study on a vector controlled area. Rev. Inst. Med. Trop. Sao Paulo 45, 269-274.

Moraes-Souza, H., Ferreira-Silva, M.M., 2011. Control of transfusional transmission. Rev. Soc. Bras. Med. Trop. 44 (Suppl. 2), 64-67.

Ostermayer, A.L, Passos, A.D. Silveira, A.C., Ferreira, A.W. Macedo, V., Prata, A.R. 2011. The national survey of seroprevalence for evaluation of the control of Chagas disease in Brazil (2001-2008). Rev. Soc. Bras. Med. Trop. 44 (Suppl. 2), 108-121.

Pan American Health Organization (PAHO), 2009. Guia para vigilância, prevenção, controle e manejo clínico da Doença de Chagas aguda transmitida por alimentos. PANAFTOSA-VP/OPAS/OMS, Rio de Janeiro.

Passos, A.D., Silveira, A.C., 2011. Summary of results from the national surveys. Rev. Soc. Bras. Med. Trop. 44 (Suppl. 20), 47-50.

Passos, A.D., Nogueira, J.L., Figueiredo, J.F.C., Gomes, U.A., Dal-Fabbro, A.L., 1997. Course of serologic positivity to Chagas disease in a rural community in Brazil. Rev. Panam. Salud Publica 2, 247-252.
Peñaranda-Carrillo, R., Moreira, E.F., Silveira, A.C., Leite, J., Vinhaes, M.C., Castro, C., et al., 2002. Evaluation of the impact of vector control programs through serological testing in Mambaí/Buritinópolis, Goiás State. Rev. Soc. Bras. Med. Trop. 35, 331-338.

Pereira, J.B., Coura, J.R., 1986. Morbidity of Chagas disease. Cross sectional study in an endemic area, Virgem da Lapa, Minas Gerais. Rev. Soc. Bras. Med. Trop. 19 139-148.

Pereira, J.B., Coura, J.R., 1987. Morbidity of Chagas disease in urban populations of the Paraiba sector. Rev. Soc. Bras. Med. Trop. 20, 101-107.

Ramos Jr., A.N., Martins-Melo, F.R., Barbosa, J.C., Heukelbach, J., 2010. The role of operational research and the challenges for integration of care and control of Chagas disease in the Brazilian Unified Health System. Rev. Soc. Bras. Med. Trop. 43 (Suppl. 2), 12-17.

Ramos Jr., A.N., Carvalho, D.M., 2001. The various meanings of Brazil's certification as free of Chagas disease. Cad. Saude Publica 17, 1403-1412.

Ramos Jr., A.N., 2004. Inclusion of Chagas' disease reactivation as a condition for AIDS case definition to epidemiological surveillance in Brazil. Rev. Soc. Bras. Med. Trop. 37, 192-193.

Ramos Jr., A.N., Carvalho, D.M., 2009. Chagas' disease: past, present and future. Cad. Saude Colet. 17, 787-794

Schmunis, G.A., Yadon, Z.E., 2010. Chagas disease: a Latin American health problem becoming a world health problem. Acta Trop. 115, 14-21.

Schur, N., Hürlimann, E., Garba, A., Traoré, M.S., Ndir, O., Ratard, R.C., et al., 2011. Geostatistical model-based estimates of schistosomiasis prevalence among individuals aged $\leq 20$ years in West Africa. PLoS Negl. Trop. Dis. 5, e1194.

Schur, N., Hürlimann, E., Stensgaard, A.-S., Chimfwembe, K., Mushinge, G., Simoonga C., et al., 2013. Spatially explicit Schistosoma infection risk in eastern Africa using Bayesian geostatistical modelling. Acta Trop. 128, 365-377.

Silva, A.V., Silva, A.W.T., Araújo, D.A., Velasquez, L.G., Correa, N.A.B., 2009. Soroepidemiology of Chagas disease in Porto Figueira District of Alto Paraíso-Paraná. Arq. Cienc. Saude UNIPAR 13, 211-215.

Silva, E.M., Rocha, M.O., Silva, R.C., Paixão, G.C., Buzzati, H., Santos, A.N., et al., 2010 Clinic and epidemiological study on Chagas disease in the Serra Azul district of Mateus Leme, central-western region of the State of Minas Gerais, Brazil. Rev. Soc. Bras. Med. Trop. 43, 178-181.

Silva, R.A., Goldenberg, P., 2008. Chagas' disease in Porto Leticia, Sao Paulo: a comparative study in the Pontal the Paranapanema. Rev Soc Bras Med Trop. 41 621-627.

Silveira, A.C., 2011a. New challenges and the future of control. Rev. Soc. Bras. Med. Trop. 44 (Suppl. 2), 122-124.

Silveira, A.C., 2011b. Entomological survey (1975-1983). Rev. Soc. Bras. Med. Trop. 44 (Suppl. 2), 26-32.

Silveira, A.C., Dias, J.C., 2011. The control of vectorial transmission. Rev. Soc. Bras Med. Trop. 44 (Suppl. 2), 52-63.

Silveira, A.C., Silva, G.R., Prata, A., 2011. Seroprevalence survey of human Chagas' infection (1975-1980). Rev. Soc. Bras. Med. Trop. 44 (Suppl. 2), 33-39.

Tachibana, H., Paz, K.C., Landivar, W.H., Kobayashi, S., Montenegro, L.T., FigueredoSilva, J., et al., 1999. Survey for Trypanosoma cruzi infection in a municipality in northeast Brazil. Tokai J. Exp. Clin. Med. 24, 131-136.

Valente, V.C., Valente, S.A., Noireau, F., Carrasco, H.J., Miles, M.A., 1998. Chagas disease in the Amazon Basin: association of Panstrongylus geniculatus (Hemiptera: Reduviidae) with domestic pigs. J. Med. Entomol. 35, 99-103.

World Health Organization, 2010. Chagas' disease (American trypanosomiasis) fact sheet (revised in June 2010). Wkly. Epidemiol. Rec. 34 334-336. 